\title{
PROOF AND EVALUATION OF PAIN AND SUFFERING IN PERSONAL INJURY LITIGATION
}

\author{
JACK H. OlendeR*
}

PAST, PRESENT AND FUTURE "pain and suffering" are wellrecognized elements of damages in personal injury actions. ${ }^{1}$ Medical science in its present state of development offers considerable aid in determining existence of pain resulting from personal injury and in predicting probabilities of future pain. Unfortunately, it is less helpful in establishing the severity of pain and suffering with much precision. Therefore, as would be expected, the problem of evaluating pain and suffering is a difficult one for juries. The current split of authority on the propriety of plaintiff's counsel utilizing mathematical formulae for evaluating pain and suffering in argument before the jury is a result of these inherent difficulties in evaluation of pain.

In this article, first the legal theories for evaluating pain and suffering are considered. Then, the nature of pain and methods for its measurement are discussed. Next, the methods of proving pain and suffering are examined, and last, pain and suffering as an element of damages is evaluated.

I.

\section{What Is Pain and Suffering "Worth"?}

The fact-finder determines what pain and suffering is worth, or,

* A.B. 1957, LL.B. 1960, University of Pittsburgh, LL.M. 1961, George Washington University. Member of the District of Columbia Bar. This article is based on a thesis submitted in partial fulfillment of the LL.M. degree requirements at the George Washington University School of Law. The author gratefully acknowledges the helpful guidance of Professor J. Forrester Davison.

${ }^{1}$ Recovery for past pain and suffering is also allowed in survival actions. Although the statutes vary from jurisdiction to jurisdiction, survival acts generally allow the estate to recover for the pain and suffering of the deceased along with other damages the deceased could have recovered had he lived. For a comparison of survival acts with wrongful death acts (which generally do not make pain and suffering compensable), see Prosser, Torts § IOS (2d ed. 1955).

Workmen's compensation, as an attempt to compensate disabled workmen for their disabilities, is aimed at pecuniary loss, and so direct recovery for pain and suffering is not part of the awards. I LARSON, WORKMEN's COMPENSATION \$ 2.40, at Io (1952). However, many tests for impairment (the medical basis for disability) utilize the prin- 
more correctly, what will compensate the plaintiff for his pain and suffering. ${ }^{2}$ There is a split of authority as to whether counsel may aid the jury by suggesting the use of a mathematical formula in the computation of damages. ${ }^{3}$ The cases indicate that the jury, either with or without aid of the mathematical formula, is kept within some limits by the appellate courts.

\section{A. Mathematical Formula}

The current controversy over plaintiff's counsel's use of a mathematical formula for damages in his argument to the jury deserves more than passing notice, for the nature of pain and suffering is at the heart of the controversy. By this method, the recovery desired for pain and suffering is represented by a per diem dollar amount for past pain and suffering multiplied by the number of days from injury to trial and by a per diem dollar amount for future pain and suffering multiplied by the plaintiff's life or pain expectancy." One of the method's ablest advocates, Melvin M. Belli, utilizes a blackboard in making the per diem argument, ${ }^{5}$ as do many others. ${ }^{6}$ However, other visual devices, as well as purely oral argument, can serve as media for conveying the per diem idea.

In a much-cited 1958 New Jersey case, Botta v. Brunner,? a new trial was granted on the question of damages because plaintiffs counsel

ciple that movement and use are effectively restricted when painful; thus, the proof of pain can be important in workmen's compensation cases.

2 "Compensation" is all the plaintiff is entitled to. McCormick, Damages $\S \S 20$, 137 (1935). The court, in its instructions to the jury, must convey this idea of compensation. In refusing to reverse judgment for plaintiff on the ground that a charge to "see what you think the pain and suffering . . . are worth" was incorrect, a Pennsylvania court said: "Though 'compensation' is an approved word in instructions in cases of this kind, it is not an infallible guide to a just verdict. ... it is a matter of observation that few philologists get on juries. We believe that only a philologist would appreciate the difference between the word 'compensation' and the word 'price' or 'worth' as used in instructions to be considered by juries in assessing damages for the elements referred to." Herb v. Hallowell, $304 \mathrm{~Pa}, 128,134-35,154$ Atl. 582, 584-85 (193 I).

See Annot., 60 A.L.R.2d 1347 (1958). Among the many articles on the subject, good case analyses are found in 10 KAN. L. REv. 93 (1961); 12 RUTGers L. REv. 522 (1958); 14 U. Fla. L. REv. 189 (1961); 28 U. CINC. L. REv. 138 (1959).

Even in the absence of per diem argument, mortality tables have been held relevant "to the length of time she would carry the injury and endure the pain" and, thus, admissible. Barone v. Forgette, 286 App. Div. 588, 146 N.Y.S.2d 63 (1955).

I Belli, MODERN Trials 846-918 (1954).

- E.g., Henne v. Balick, 51 Del. 369, 146 A.2d 394 (1958).

26 N.J. 82, 138 A.2d 713 (1958). For a recent case disapproving of the 8 . called "mathematical formula argument" but nevertheless upholding it, see Hall v. Booth, 178 N.E.zd 619 (Ohio App. 1961). 
had used the mathematical formula in his argument to the jury. The court reasoned that pain and suffering damages are of such a nebulous nature that "the law has declared the standard for measuring damages for personal injuries to be reasonable compensation and has entrusted the administration of this criterion to the impartial conscience and judgment of jurors...." The per diem figures were thought to "have no foundation in the evidence. They import into the trial elements of sheer speculation on a matter which by universal understanding is not susceptible of evaluation on any such basis." The court further reasoned that the defendants would be prejudiced if the per diem mathematical formula were allowed, since they would be under pressure to submit per diem rates of their own to contest the plaintiff's rates. Thus, the defendants would be forced to acknowledge before the jury the proposition that the law recognizes pain and suffering as capable of evaluation on such a basis. ${ }^{10}$

New Jersey seems to have retreated from this position to some extent. A later case permitted the listing on a blackboard, along with other claimed damages, of the number of days since the accident and the life expectancy of the plaintiff under the category "pain and suffering."11 Thus, even though dollar amounts were not filled in, it would seem that the per diem idea was conveyed to the jury. ${ }^{12}$ If it is conceded that the time element is a factor, it seems inconsistent with such concession to forbid counsel to suggest a dollar rate. Counsel is ordinarily permitted to suggest to the jury all reasonable inferences that it may make from the evidence so long as it is made clear that the argument of counsel is not evidence. ${ }^{13}$ Similarly, plaintiff's counsel should be permitted to

Botta v. Brunner, 26 N.J. 82, 94, 138 A.2d 713, 7r9 (1958).

'Id. at 100, 138 A.2d at 723 .

${ }^{20}$ Id. at 101,138 A.2d at 723-24.

${ }^{21}$ Cross v. Robert E. Lamb, Inc., 60 N.J. Super. 53, 158 A.2d 359, certification denied, 32 N.J. 350,160 A.2d 847 (1960). One writer suggests that plaintiff's counsel should be allowed to recommend a method for measuring pain and suffering but forbidden to make any reference to monetary figures to be used in the system. It is said that this method "would leave entirely to the jury the estimation of those damagcs which cannot be measured by any standard of pecuniary value." Comment, Argumerse of Counsel-The Measure of Damages for Pain and Suffering, 15 U. Miami L. REv. $85,94(1960)$.

${ }^{13}$ However, the court said that the listing did not connote to the jury that it should first determine a rate and then multiply by the time element. Cross v. Robert E. Lamb, Inc., 60 N.J. Super. 53, 76, 158 A.2d 359, 372 (1960).

${ }_{12}$ Jones v. Hogan, 56 Wash. 2d 23, 35I P.2d 153 (1960). The mathematical formula and blackboard technique were approved in this case, with the court noting that sufficient mentality to distinguish between argument and evidence must be attributed 
suggest the correct dollar inference, leaving defendant's counsel free to counteract such statements with suggestions of his own. ${ }^{14}$

Although the legal reason for prohibiting use of the mathematical formula may be the ease with which it can be confused with evidence, ${ }^{15}$ the defendant's major reason for opposing it is its tendency to inflate the award. ${ }^{18}$ When the formula is used, the jury is encouraged to think of the pain and suffering as a day-to-day burden, and while 100,000 dollars may seem a fantastic sum to award for pain and suffering, ten dollars per day may seem hardly enough. A Texas court recognized that the per diem system is likely to result in higher verdicts than "by guess and by golly" selection of a total pain and suffering amount, but regarded the per diem method "more reasonable and accurate," especially when "the evidence establishes both the period and evidence from which an average daily degree of pain might be inferred, together with a value thereof."17

In others cases rejecting the Botta v. Brumner view, the difficulty in evaluating pain and suffering has been given as a reason for allowing counsel to suggest proper inferences to the jury. ${ }^{18}$ That the per diem method may be helpful to fact-finders other than reputedly impressionable lay jurors is indicated by an admiralty case in which the judge,

to the jury. "This is especially true after the court has instructed that any remark of counsel not sustained by the evidence should be disregarded." Id, at 32, 35 I P.2d at 159.

is It has been held permissible for plaintiff's counsel to invite defendant's counsel to change the figures to what he thinks they should be. Roberts Const. Co. v. Henry, 265 Ala. 608, 616, 93 So.2d 498, 505 (1957). However, too much dignity must not be afforded the blackboard figures; they must remain adjuncts to argument; for example, the photographing of the blackboard in the jury's presence was held improper in that it would overly impress the jury with the importance of the blackboard figures. Affett v. Milwaukee \& Suburban Transp. Corp., II Wis. 2d 604, 614, 106 N.W.2d 274, 280 (1960).

${ }_{15}$ The Botta ข. Brunner court considered mathematical formula suggestions as "argument, which in effect becomes testimony." Botta v. Brunner, 26 N.J. 82, 100, 138 A.2d 713, 723 (1958). The Delaware court equates such argument with evidence: "Plaintiff was permitted by means of blackboard a demonstration . . . to put in the record evidence which he would not otherwise be permitted to introduce." Henne v. Balick, 5 I Del. 369, 376, 146 A.2d 394, 398 (1958).

${ }^{10}$ The University of Chicago jury project data, however, is said to indicate that the jury takes a "gestalt" rather than item-by-item approach to damages. Kalven, The Jury, The Law, and the Personal Injury Damage Award, I9 OHIO ST. L.J. 158, I6I (1958).

${ }_{17}$ Continental Bus System, Inc. v. Toombs, 325 S.W.2d 153, 165 (Tex. Civ. App.

1959). Just what the value implied by the evidence was, is not clear.

18 E.g., Ratner v. Arrington, 1 I I So. 2 d 82 (Fla. App. 1959). 
sitting as fact-finder, used the per diem mathematical formula to compute pain and suffering damages. ${ }^{10}$

Since "reasonable compensation" is the criterion for pain and suffering awards, it would not seem that awards should be reduced to present worth. The award is not the money equivalent of the right to be free from pain, as it is for loss of earnings, so it should not be discounted. Most of the cases have so held, ${ }^{20}$ but some require reduction to present worth. ${ }^{21}$ The strongest argument for reduction to present worth can be made when the mathematical formula is used, for it seems somewhat less illogical to discount a sum arrived at by a more precise method than by the "by guess and by golly" method. ${ }^{22}$

A problem related to the use of the mathematical formula is that concerning the ad damnum clause. The New Jersey court adopted the Pennsylvania rule which does not allow the jury to learn the total amount being sued for. ${ }^{23}$ The court in Botta $v$. Brunner stated that even though the court admonishes the jury that the ad damnum clause represents only the plaintiff's claim and that their award must be based on the principle of reasonable compensation, "it is extremely doubtful whether such admonitions are sufficient to eliminate the figure from their minds as a conscious or unconscious factor in reaching their verdict." 24

It is suggested here that both the ad damnum clause and the per diem mathematical formula are properly presented to the jury. Pos-

\footnotetext{
10 Imperial Oil, Ltd, v. Drlik, 234 F.2d 4 (6th Cir. 2956).

${ }^{20}$ E.g., Yost v. West Penn. Ry., 336 Pa. 407, 410, 9 A.2d 368, 370 (1939); see Annot., 154 A.L.R. 796, 801 (1945).

"21 E.g., Johnson v. Lewis, 251 N.C. 797, 804, 112 S.E.2d 512, 577 (2960).

${ }^{28}$ In Braddock v. Seaboard Air Line R.R., 80 So. 2d 662, 668 (Fla. 1955), a case in which the mathematical formula was used, the court disapproved of reduction to present worth.

${ }^{83}$ Stassun v. Chapin, $234 \mathrm{~Pa} .125,188$ Atl. 211 (1936).

26 Botta v. Brunner, 26 N.J. 82, 104, 138 A.2d 713, 725 (2958). The ad damnum clause has been judicially criticized "as the equivalent of the asking price .... inserted in the complaint before any evidence is in the record." Affett v. Milwaukee \& Suburban Transp. Corp., II Wis. 2d 604, 6x4, 106 N.W.2d 274, 280 (1960). One writer says the ad damnum clause "has been adopted . . . by plaintiffs as a psychological weapon to get the jury in the swing of big figures. It starts off as a slow beat of the music which finally ends in a war dance. It is fantasy which an attorney sometimes makes real with the aid of a piece of chalk and a blackboard." Bradford, How to Talk Dollars and Cents to the Jury, 1959 INs. L.J. 567, 569. The results of a questionnaire published in the Bradford article indicate that in most jurisdictions specified amounts are demanded in the pleadings (47-2); the jury is informed of the amount claimed (by the court 39-7; by plaintiff's attorney 31-5); and the plaintiff's attorney is permitted to advise the jury of his evaluation of pain and suffering $(42-3)$. Id. at 570 .
} 
sibly, the unenunciated reasons for excluding them are the thought that pain and suffering should not be compensable or, if so, only to a limited degree, or that the lay jury is not competent to evaluate conflicting facts and theories in making an award. If any of these suggested reasons has validity, the solution is not in withholding problem-solving ideas from the jury, but in attacking the problems more directly and less hypocritically. Effectuation of the second suggested reason for prohibiting the per diem argument, that of limiting recovery for pain and suffering, is frequently brought about through the powers of appellate courts to set aside excessive verdicts.

\section{B. Standards}

It might . . . be said that it is fruitless to search for any norm to measure compensation for intangible painful consequences of a wrongful injury. On the other hand there must be a norm, otherwise how can the rule state that a verdict may not be set aside as excessive unless it be "wholly unwarranted," "palpably excessive" and so on. The very words used in the rule presuppose a norm. There is no evidence upon which the jury can decide because there is no evidence in any record itself which tells the jury how to go about deciding how much to allow for intangibles and therefore the range of the verdict would be limitless. But everyone admits there must be a limit .... The test is limited to the question of the fairmess of the award for the intangibles. ... 25

The above statement describes the situation about as well as possible; there is no standard other than "fairness," etc. The "golden rule" criteria_-"what would you take for this condition?"-is improper. ${ }^{28}$ The award for pain and suffering is to be determined by the jury and its verdict will not be interfered with so long as it constitutes a reasonable judgment. ${ }^{27}$ Where the verdict is excessive, a remittitur will usually be ordered on penalty of having the judgment reversed and a new trial ordered. ${ }^{28}$ Where the verdict is not only excessive but also the result of passion and prejudice a new trial will be ordered, since it is difficult or impossible in such case to determine what part, if any, of the award

\footnotetext{
${ }^{23}$ Justice Kiley, specially concurring in Goertz v. Chicago \& N.W. Ry., i 9 Ill. App. 2d 261, 275-76, 153 N.E.2d 486, 494 (1958).

${ }_{28}$ Red Top Cab Co, v. Capps, 270 S.W.2d 273, 275 (Tex. Civ. App. 1954).

"Margaret Ann Super Markets v. Scholl, 159 Fla. 748, 754, 34 So. 2d 238, 241 (1948).

25 "There was no indication that the verdict was the result of passion -or prejudice." Leinbach v. Pickwick Greyhound Lines, 138 Kan. 50, 69, 23 P.2d 449, 458 (1933).
} 
should be allowed to stand. ${ }^{29}$ The degree of excessiveness appears to be the distinction between a verdict that is merely excessive and one that is the result of passion and prejudice. ${ }^{30}$ In the converse situation, where the award is insufficient, the appellate courts generally do not award an additur for unliquidated damages such as pain and suffering. ${ }^{\text {a1 }}$ But where no damages are given by the jury for pain and suffering and the evidence clearly establishes pain and suffering, a new trial may be ordered. ${ }^{32}$

Although the standard is "reasonableness" or "fairness," certain criteria have been used by the courts in determining whether an award is excessive. In the case quoted at length at the beginning of this subsection, the court reduced a 300,000 dollar award to 200,000 dollars. Both legs and the left arm of the plaintiff had been amputated as a result of the defendant's negligence. A concurring justice calculated the jury's award as giving seventy per cent of the total award for the element of pain and suffering as compared with an average allowance of about forty per cent in "relevant Illinois cases."33 He compared the awards in light of plaintiff's life expectancy and the life expectancies in these "relevant Illinois cases" and concluded that plaintiff would be receiving more per year for pain and suffering than previous plaintiffs had received. ${ }^{34}$ Such analysis presupposes that the prior awards are relevant; that is, that the prior awards represent the upper limit of

\footnotetext{
${ }^{20}$ Minneapolis, St. Paul \& Sault St. Marie Ry. v. Moquin, 283 U.S. 520,521 $(1931)$.

${ }^{30}$ Compare the two Leinbach cases. In the first, 135 Kan. 40, 10 P.2d 33 (1932), a new trial was ordered since the $\$ 62$, 10o verdict for the "severely, variously and painfully injured" plaintiff (id. at $43,56,10$ P.2d at 35,41 ) was considered as having "manifestly been given under passion and prejudice." (Id. at 57 , 10 P.2d at 42 ). In handling the appeal of the second trial, the court reduced the $\$ 27,000$ personal injury verdict to \$20,000. 138 Kan. 50, 23 P.2d 449 (1933).

${ }^{31}$ See Annot., 56 A.L.R.2d 213 (1957).

${ }^{32}$ McCaslin v. Ellsworth Coal Co., IIg Kan. 93, 237 Pac. 658 (I925); Carter v. Skelly Oil Co., 317 S.W.2d 227 (Tex. Civ. App. 1958).

${ }^{32}$ Goertz v. Chicago \& N.W. Ry., 19 Ill. App. 2d 261, 277, 153 N.E.2d 486, 494 (1958). A year later, in Lau v. West Towns Bus Co., 16 Ill. $2 d$ 442, $15^{8}$ N.E.2d 63 (1959), the fact that only $\$ 1,500$ of a $\$ 75,000$ award was for special damages did not render the award excessive, for "we cannot limit compensable damages for pain and suffering to a set percentage of medical, hospital and kindred expenses. Costly surgery may result in complete recovery for one person, while the total of the foregoing expenses incurred by a multiple amputee may be small." Id. at 453,158 N.E.2d at 69. See also Louisville \& Nashville R.R. v. Mattingly, 339 S.W.2d 155, 160-6r (Ky. 1960).

"Goertz v. Chicago \& N.W. Ry., 19 Ill. App. 2d 261, 275, 153 N.E.2d, 486, 494 (1958).
} 
what should be awarded in a case of the same general nature. Although courts which compare verdicts ${ }^{35}$ make allowance for the decreasing purchasing power of the dollar in their comparisons, ${ }^{38}$ again, it must be assumed that the earlier cases were at the time of decision correct statements of the maximum award that should have been allowed.

A defendant-minded court enunciated the idea that is apparently behind the reduction of awards; that is, concern for the economic burden of the defendant. After stating that the defendant bus company could not make enough profit to pay the verdict of 62,100 dollars with a round-trip to the moon, the court observed:

[T] his court has had to deal with many cases of severely and permanently injured persons, and hitherto it has steadfastly set its face against the perversion of a cause of action for personal injuries into a letter of marque to plunder the treasury of a corporation. ${ }^{37}$

More recently it has been observed that changing social and economic concepts are influencing courts and juries to place higher values on the rights of human beings to remain free of bodily injury. ${ }^{38}$

Some commentators view disparities in awards for identical injuries as undesirable and would welcome a "scientifically well-founded method of making reasonable appraisal of the damages."30 Are attempts at standardization of damages for pain and suffering desirable? In answering this question, pain and suffering should be placed in perspective as part of the compensable aftermath of the traumatic event. The other parts of the compensable aftermath are more purely pecuniary-medical expenses, etc., and loss of income through disability. These differ, of course, from individual to individual in direct proportion to the quantity and quality of treatment given and to the diminution of earning capacity. For example, a plaintiff earning 100,000 dollars per year prior to an accident who has had his earning potential cut to 50,000 dollars per year will be awarded more for loss of future earnings than will a 4,000 dollars per year man, with the same life expectancy, cut to 2,000 dol-

\footnotetext{
${ }^{85}$ See Catalano, Negligence Law: The Theory of Comparable Verdicts, 45 C.B.A.J. $811(1959)$.

${ }^{80}$ Sandifer Oil Co. v. Dew, 220 Miss. 609, 625-26, 71 So. 2d 752, 755-56 (1954); Texas \& N.O. Ry. v. Coogler, 209 S.W.2d 778 (Tex. Civ. App. 1948).

"' Leinbach v. Pickwick Greyhound Lines, 135 Kan. 40, 56, 19 P.2d 33, 41 (1932). See note 30 supra.

${ }^{88}$ Karlin, Bodily Injury Awards-Where Are We Going?, 1957 INs. L.J. 568, 570.

"Prager, Computation of Damages in Personal Injury, 4 KAN. L. REv. 91 (1955). See also Zelermeyer, Damages for Pain and Suffering, 6 SYrAcuse L. REv. 27, 41-42 (1954).
} 
lars. It is accepted that primarily pecuniary injuries should be compensated for in accordance with the particular facts; that is, the award should vary from person to person in direct proportion to actual pecuniary loss. Likewise, the non-pecuniary elements, those for pain and suffering, should be geared to meet the individual case.

So long as pain and suffering is compensable, judicial notice should be taken of what is becoming common knowledge-different individuals react differently, both physically and emotionally, to similar sets of events. A blow which inflicts only an inconsequential bruise on one person may trigger in another a painful syndrome which makes his life burdensome. The tortfeasor's liability for the non-pecuniary effects on his victim's life should not be restricted by arbitrary standards in conflict with the principle that the tortfeasor must take his victim as he finds him. The concept of individual differences is recognized by those courts which consider the age, health, habits and pursuits of the plaintiff relevant to the size of his award.10

The differences in individual responses which necessitate individual treatment of damages are discussed in the next section.

\section{II.}

\section{The Nature of Pain}

\section{A. Can We Measure Pain?}

If science can unequivocally answer "yes" to this question, some changes in persoual imjury litigation can be predicted. The courts proscribing the use of a mathematical formula for pain and suffering will have to re-examine their position. For example, the Botta v. Brumner court said "there is no measure by which the amount of pain and suffering endured by a particular human can be calculated" ever argued that a witness, expert or otherwise, would be competent to estimate pain on a per hour or per diem basis."22 Methods of objectively

${ }^{10}$ Van Gordon v. United States, 91 F. Supp. 834, 835 (W.D. Mo. 1950) 3 cf. Sykes v. Brown, I56 Va. 881 , 159 S.E. 202 (1931). However, the plaintiff's standing in life is not necessarily determinative of what his pain and suffering damages should be. "The elements that enter into a judgment like this are so diverse that it often requires more of humility than it does of law properly to assess them. The Judge who overlooks the fact that the lineman, the yardman, the plumber and the cook are inade of the same common clay that he is, is not equipped to do so." Florida Power \& Light Co. v. Hargrove, $160 \mathrm{Fla} .405,410,35$ So.2d I, 3 (1948).

${ }^{4}$ Botta v. Brunner, 26 N.J. 82, 93; 138 A.2d 713, 718 (1958).

${ }^{42}$ Id. at 100,138 A.2d at 723 . 
measuring pain would invalidate the premise for denying the mathematical formula. Probably of more importance, the proof and evaluation of pain would be made relatively simple.

In this section, some of the work on pain will be noted in an attempt to determine to what extent pain can be measured. Generally, it should be said that in the context of personal injury litigation, pain cannot be measured with any degree of accuracy approaching that possible in diagnosing a relatively uncomplicated fracture. But the present state of medical science does offer some aids in the proof and evaluation of pain. Before examining some of the methods of proving, measuring or evaluating pain, the nature of pain as it is currently understood will be considered.

\section{B. Definition and Mechansics of Pain}

Unless he is one of those rare and unfortunate individuals in whom pain perception is congenitally absent, ${ }^{48}$ one can define pain introspectively. No attempt will be made to define it here, for medical experts admit that they do not know just what it is. ${ }^{44}$ Neither is it understood exactly how the pain mechanism works. ${ }^{45}$ It may be said very generally that pain impulses originate in nerve terminals throughout the body and somehow are transmitted through various fibers and routes to regions of the brain where they are perceived or "appreciated" and where physical and mental reactions are initiated. ${ }^{48}$

The common nervous headache is an example of the interaction of the psyche or mental processes and physical or somatic processes in the pain experience. It is believed that the perception of and reaction to all types of pain is affected by the individual's history and personality and the circumstances in which the noxious stimuli are encountered.47

\footnotetext{
"Such persons do not have the benefit of pain as 2 protective warning device. The cause of this rare condition is unknown. Steindler, INTERPREtation of PAin in ORTHOPEDIC PRACTICE 17-18 (1959).

“ BeEcher, MEasurement of SUbJective Responses: Quantitative Effects OF DRUGS 7 (1959).

4 White \& Sweet, Pain, Its Mechanisms and Neurological Control 66 (1955); Kelly, Does Pressure on Nerves Cause Pain?, 1960 MED. J. AustL. I18 (No. s).

"WolfF \& Wolf, PAin 5-8 (1958); MacBryde, Signs and Symptoms 8-9 (1952). Exactly how this works is not known. It would seem that we are a step closer to understanding this mechanism because of the work of Columbia University biochemists who studied the chemicals involved in the transmission of impulses through nerves. Nachmansohn, Role of Acetylcholine in $A$ xomal Conduction and Neuromuscular. Transmission, 38 AMER. J. PhYs. MED, 190 (Oct. 1959).

"E.g., Melzack, The Perception of Pain, 204 Scientific American 4 I (Feb.
} 
One writer says that "all of these factors play a role in determining actual patterns of nerve impulses ascending to the brain and traveling within the brain itself."

The idea that "for a given stimulus there must be a given response; that is, for so much stimulation of pain endings, so much pain will be experienced" is fundamental error. ${ }^{49}$ Dr. Beecher of Massachusetts General Hospital says further that apparently pain is experienced "only if an essential psychological state (anxiety, stress) is present. Physiological derangement (stimulation of pain endings) is not enough." To support this conclusion, Dr. Beecher compares his war experience with wounded soldiers with a study of civilian surgical patients. ${ }^{51}$ Of all the severely wounded soldiers considered in his observations, only one-third, on being directly questioned shortly after entry into a forward hospital, said their pain bothered them enough to require relief. In contrast, of the male civilian patients who had undergone major surgery with far less tissue trauma than the soldiers, four-fifths wanted medication to relieve their pain. The behavior of the soldiers cannot be attributed to shock for they were mentally clear, and they did not have total pain block, for they complained vigorously at inept venipuncture. The explanation:

The important difference in the two groups seems to lie in their responses to the wounds. In the wounded soldier it was relief, thankfulness for his escape alive from the battlefield, even euphoria (his wound was a good thing); to the civilian his major surgery, even though essential, was a depressing, calamitous event. The civilian group's pain was strikingly more frequent and more severe than that of the soldiers. These data state in numerical terms what is known to all thoughtful clinical observers: There is no simple, direct relationship between the wound per se and the pain experienced. The pain is in very large part determined by other factors, and of great importance here is the significance of the wound, i.e., reaction to the wound. .2 $^{52}$

Studies on the relief of pain also provide evidence that psychological

196I); Rome, The Problem of Pain, 3I Staff Meetings of the Mayo Clinic $22 \mathrm{I}$ (1956).

${ }^{8}$ See Melzack, supra note 47 , at 49 .

$\triangle 9$ BEECHER, op. cit. supra note 44 , at $x$.

${ }^{\text {so }}$ Beecher, Increased Stress and Effectiverress of Placebos and "Active" Drugs, 132 SCIENCE 91-92 (1960).

${ }^{51}$ BEECHER, op. cit. supra note 44, at 164-65; Beecher, Relationship of Significance of Wound to Pain Experience, 16 J.A.M.A. 1609 (1956); Beecher, Pain in Men Wounded in Battle, 123 AM. SURGERY 96 (1946).

"SEECHER, op. cit. supra note 44, at 165 . 
elements are important in pain syndromes. Small doses of morphine have been found more effective in relieving post-operative pain than larger doses have in altering experimental pain. ${ }^{83}$ The significant postoperative pain was more amenable to treatment. From another study ${ }^{64}$ it can be further concluded that relief obtained in the stress situation, i.e., post-operative pain, was attributable to suggestion as well as to the analgesic properties of morphine. It was found that the placebo, an inert agent, relieved forty per cent of a group of patients in great pain whereas morphine relieved fifty-two per cent. The placebo, of course, was not revealed as such. Later when the pain was much less, the inert agent relieved twenty-six per cent and the morphine relieved eighty-nine per cent. Thus, it appears that the power of suggestion ${ }^{35}$ is greatest when pain is greatest. It has likewise been shown that a placebo's effectiveness increases as anxiety increases. ${ }^{56}$ Since the placebos are effective in dealing with severe pain and since they can affect only psychological processes, it seems that stress and other psychological factors are important components of severe pain. ${ }^{57}$ "The rigid dichotomy of organic pain versus psychogenic pain has become obsolete, and pain must be considered and approached clinically as a Gestalt problem. . . . .68

In Beecher's studies utilizing these placebos, he found that there is a group that consistently reacts to them. ${ }^{59}$ It will be recalled that reaction to placebos is an indication that the patient's psyche is playing a major role in his pain experience. Thus, it would appear that the pain experience of the group of persons who are consistent reactors is largely controlled by psychological factors. ${ }^{80}$ Beecher says that the

\footnotetext{
${ }^{83} I d$. at 164 . $I d$. at 170 .

"65 The power of a placebo has been likened to that of hypnotism. Id. at 185 .

${ }^{80} I d$. at 185 .

${ }^{87}$ Beecher, supra note 50, at 91.

${ }^{88}$ Cooper \& Braceland, Psychosomatic Aspects of Pain, 34 MEd. CLINics No. AMEr. 981 (1950). The article contains a diagram of a "pain spectrum" representing the relative parts neurologic and psychiatric factors play in various pain syndromes in different individuals. At one end is the pain of predominately physical origin and at the other, that of the malingerer. By definition, a spectrum does not have sharp dividing lines between different "categories." The individual pain case will fall more into one particular area than into the other areas of the spectrum.

${ }^{80}$ BEECHER, op. cit. supra note 44 , at 68-69.

${ }^{\circ 0}$ Perhaps it would be more accurate to say that the physical and mental set of the consistent reactor predisposes him to relief of his pain. The difference between these two statements of conclusion is, perhaps, semantic only, but the difference in psyche in the -placebo reactors and non-reactors may be qualitative rather than quantitative; i.e., the psyche is important in all pain experience but is more obvious where the results are not in accord with what would be expected absent the psychological elements.
} 
placebo reactor is identifiable by psychological testing and interviewing, but, regrettably, he does not say what the specific traits of a reactor are other than that there are significant differences between his "attitudes, educational background, and personality structure" and those of a nonreactor. ${ }^{61}$

Several studies using experimentally induced pain should be mentioned here. ${ }^{62}$ It is reported that "examination of 150 coal miners revealed that over $75 \%$ were hyposensitive to pain. ... These findings suggest that a hazardous occupation over a period of years may be a predisposing cause in raising a patient's threshold to pain. ..." ${ }^{\text {B3 }}$ They may also suggest, among other things, that men relatively insensitive to pain enter into the mining occupation.

The results of another study indicate that (I) women are more sensitive to pain than are men, (2) French-Canadians and Jews are more sensitive to pain than Anglo-Saxons, and (3) pain sensitivity decreases with age. ${ }^{\text {os }}$ This last finding is in accord with the belief that "sensitivity is learned by the infant, increases to adult life, and then gradually diminishes...." Countering this reported tendency of elderly people in the experimental situation, is the "facilitated pain" phenomenon. As pain is continued over a period of time, resistance to conduction of the impulses to the brain is reduced. This is probably the reason chronic rheumatics are so sensitive as to be able to predict changes in the weather. ${ }^{68}$

Some individuals are reported to have a tendency to reduce perceptions, including that of pain. In one experiment, the subjects were blindfolded and instructed to continuously rub a block and then judge

"Dr. Beecher does eliminate certain factors from relevancy: "It was clear that the placebo reactors did not belong to the lunatic fringe of the population; they were neither whiners nor notable incompetents, neither male nor female, neither young nor old, predominately. Their average intelligence was the same as tbat of the non-reactors." BEECHER, op. cit. supra note 44 , at 69 .

"s Experimentally induced pain is discussed in greater detail at note 115 infra. The results of the experiments now being discussed should be carefully evaluated in light of the criticisms considered at notes $1 \times 6-18$ infra. They are presented here, not necessarily as an endorsement of their validity, but to give a sampling of the work and ideas in this area.

"Sherman, Sensitivity to Pain, 48 Can. M.A.J. 437 (x943).

"Sherman \& Robillard, Sensitivity to Pain in the Aged, 83 CAN. M.A.J. 944-47 (1960).

"MACBRYDE, op. cit. suppra note 46 , at 16 (1952). "The learning process in regard to pain involves the emotional, reactioe components rather than the physical components." Ibid.

"Id. at 15. 
its size. Those who tended to subjectively reduce the block were found to have a higher tolerance for experimentally induced pain than were those who tended to subjectively enlarge the block. ${ }^{67}$

Some courts have recognized individual differences in pain and suffering cases, even though no references to the reported experiments have been made. ${ }^{68}$ The recognition of these differences is based on common knowledge. Should the results of the reported studies be admitted into evidence in personal injury litigation to show that the plaintiff, because he falls into certain categories, is either hyposensitive or hypersensitive to pain? If they are, precautions must be taken: the experiment must be proven valid, i.e., it must measure what it says it measures; reliable, i.e., the method and controls used must be such that the results are reproducible; and relevant. The differences between experimentally induced pain and pathological pain experience cast doubt on the relevancy of such data; this doubt is reinforced by the criticisms of experimental pain techniques and theories. ${ }^{60}$

\section{Psychogenic Pain}

Some current ideas on the psychology of the individual as affecting his pain experience have been surveyed above. The idea was developed that all pain experience has psychic elements. Pain syndromes where the psychological elements are dramatically manifested will now be examined. These are psychoneuroses and the pain can be called "psychogenic."70 A traumatic pain neurosis is not the same thing as malingering, which is a feigning of pain or disability on a conscious level, ${ }^{\mathbf{7 1}}$

"Petrie, Some Psychological Aspects of Pain and Relief of Suffering, 86 ANN. N.Y. ACAD. SCI. 13 (March 1960); Petrie, Collins \& Soloman, The Tolerance for Pain and Sensory Deprivation, 73 AMER. J. Psychol. 80 (1960). Sheldon \& STEVENs, THE VARIETIES OF TEMPERAMENT (1942), may be noted in passing. The authors assert that persons with "somatotonic" tendencies (predominance of somatic structure-athletic type) have "Spartan indifference to pain"; persons with "cerebrotonic" tendencies (predominance of consciousness of higher centers of nervous system-tall, thin type) are hypersensitive to pain; "viscerotonic" types (predominance of digestive viscera-fat people) are "complacent" about pain, while average individuals are more evenly balanced.

Qs Ware v. Garvey, 139 F. Supp. 71, 81 (D. Mass. 1956); Franklin v. United States, 124 F. Supp. 953, 958 (N.D. W. Va. 1954) (Federal Tort Claims Act case); Sandoval v. Southern California Enterprises, 98 Cal. App. 2d 240, 254-55, $2 \times 9$ P.2d 928,938 (1950).

"See criticisms at notes $x$ I 6-18 infra.

${ }^{70}$ Different authorities use different terminology for these concepts. The language and the terms used here are typical and not exhaustive; the purpose is to convey some of the basic ideas on pain.

${ }^{72}$ Mackay, Post-Traumatic Neuroses, 29 Industrini. Med. \& SURGery 200, 201 
and unlike malingering, it is compensable in personal injury actions. The victim is more or less unaware of the psychic nature of his affiction. The theory is that prior to the traumatic episode which triggered the neurotic syndrome, the victim was neurotic to some degree. ${ }^{72}$

It may be that the psychogenic pain was originally organically induced, but psychological factors are responsible for its perpetuation. ${ }^{73}$ Furthermore, in some cases, the prolonged obsession with pain may almost constitute the raison d'etre. ${ }^{74}$ That is, the attention of the trauma victim may become intensely fixed on the site of the injury. His concern is fed by attention from family, physicians and friends. Thus, the pain site becomes the center of his universe. ${ }^{75}$ As an attention-getter, it affords satisfaction, so he becomes a martyr to pain. ${ }^{78}$ All of this is on an unconscious level, so the pain is very real; the neurotic is not malingering.

(1960). "The line between psychoneurosis and malingering is often difficult to draw. It depends largely on how deliberately the deception is practiced. A malingerer knows perfectly well that he is falsifying; a psychoneurotic patient is more or less unaware of his motivation-it is unconsciously motivated to a much greater extent than is the case of the malingerer." WHITE \& SWEET, op. cit. supra note 45, at 104. See Hood v. Texas Indem. Ins. Co., 146 Tex. 522, 209 S.W.2d 345 (1948) (workmen's compensation); Solomon \& Smith, Traumatic Neuroses in Court, 30 VA. L. REv. 87 (1943).

Perhaps the increasing popular awareness of mental illness will effect more and larger awards for psychosomatic pain. "Television and other channels of education have taught the public to accept mental illness diagnoses from competent psychiatrists. Amend your pleadings as soon as you discover the real illness, and raise your prayer. You may now have a substantial case, where you had a slight bruise before." Sindell, MedicalLegal Preparation of a Tort Case, 2958 TRIAL AND TORT TRENDS 445, 473-74 (Belli ed.).

72 MacKay, supra note 71, at 202.

${ }^{73}$ Cooper \& Braceland, Psychosomatic Aspects of Pain, 34 Med. Clinics No. Amer. 981, 986-87 (1950); WHITE \& SWEET, op. cit. supra note 45, at 104. It is said that the converse is not true. "It is almost unheard of for . . . psychiatrists to see 2 patient whose mental illness has been precipitated by an experience with physical pain. It just doesn't produce psychiatric disability." Letter of April 19, 1961, from Dr. Herbert C. Modlin of the Menninger Clinic, Topeka, Kansas. He also says: "We see so many who bear up bravely to the severist pain with fortitude and without any permanent psychological effects. Our patients rarely make much of it, and we are inclined to be a bit puzzled by the few who seem to make a major issue of it."

For the effects of disability, a common concomitant of pain in the aftermatb of trauma, see Psychological Aspects of Physical Disability (Garret 1952), Rehabilitation Service Series No. z10, Federal Security Agency, Office of Vocational Rehabilitation. See especially the articles at pages eighteen and eighty.

"Erasmus, Studies on Pain, 25 So. AFr. M.J. 601, 603 (1951).

${ }^{78}$ It is a common experience that distraction at least makes the suffering of pain more bearable. Indeed, there is evidence that it may cause variations in pain threshold and pain sensitivity. BEECHER, op. cit. supra note 44, at 143,155 .

"Cooper \& Braceland, supra note 73, at $986-87$. 
The concept of "symbolic" or "referred" pain" describes the situation where the individual has received an injury more mental than physical, such as an insulting slap on the face, and as a result experiences physical pain that has little observable physical basis. The physical pain becomes a symbol representing the mental hurt. ${ }^{78}$ Perhaps "compensation neurosis" and "litigation neurosis" involve symbolic pain; that is, the victim unconsciously feels that he has been taken advantage of and is entitled to something. ${ }^{\text {9 }}$

An interesting theory of psychosomatic pain has been developed involving the "fight or flight" phenomenon. ${ }^{80}$ The theory is that injury or threat of injury arouses the "fight or flight" instincts-the sympathetic division of the autonomic nervous system is activated and the heart accelerates, air passages widen, sweat glands secrete, adrenalin and sugar are released into the blood stream, etc. ${ }^{81}$ However, since modern man does not usually fight or flee in situations such as an automobile accident, the tremendous amounts of nervous impulses accumulated in the body are not relieved and the physiological harmony of the nervous system is disrupted. Consequently, one of the results may be psychosomatic pain. ${ }^{82}$

Mention should be made of one more pain sensation where nonphysical factors may be very important. The sensation known as "phantom pain" sometimes follows amputation and is apparently localized where the amputated part used to be. It is consistently reported that the great majority of amputees experience this sensation of phantom pain, ${ }^{83}$

\footnotetext{
${ }^{77}$ Walters, Pain and Suffering, 36 MED. Clinics No. AMrr. 485-500 (1952).

${ }^{78}$ Since such pain may conform to psychologic rather than anatomical patterns, a non-psyche oriented diagnostician may conclude: "malingerer." See discussion of tests for pain and disability at note 83 infra.

${ }^{79}$ Gotten, Surrvey of One Hundred Cases of Whiplash Injury After Settlement of Litigation, 162 J.A.M.A. 865 (1956), concludes on the basis of the study that since most of the patients recovered after litigation was terminated, the pressure of litigation accentuates complaint. Without disputing that conclusion, it is suggested that time may also contribute to the healing.

${ }^{80}$ Pain and Suffering in Psychosomatic Injuries, 5 CUR. MED. ATTNYs. 13 -19 (Sept. 1958).

"Deep pain" (internal, as opposed to "superficial pain" which is near the surface of the body) may precipitate withdrawal activity rather than fight or flight preparation. MACBRYDE, op. cit. suppra note 46 , at Io (1952).

"2rawfis, Conversion Hysteria-An Explanation for Attorneys, 6 Clev.-MAR. L. REv. 3I (1957).

s2 Bonica, The Management of Parn 980 (1953); Erasmus, Studies on Pain, 25 So. Afr. M.J. 601, 602 (195I); Henderson \& Smyth, Phantom Limbs, i I J. Neurol., Neurosurg. ANd Psychiat. 88, to6 (New Series 2948 ).
} 
but there are variations in the incidence of pain in the phantom reported $^{84}$ Theories of the causes and mechanics of phantom pain range from the predominately physical to the predominately mental. ${ }^{86}$ In either event, however, phantom pain is compensable in personal injury actions. $^{88}$

\section{Medical Techniques for Proving, Measuring, and Evaluating Pain}

It should first be noted that search has disclosed no instances of scientists working on a pain-measuring machine designed especially for use in the court room. While machines and techniques which measure or test pain are being developed and used, their adaptability at this time for court room use is not apparent. Instead, these machines and techniques were developed for the testing of drugs, diagnoses, and psychological and sociological testing. Some of these more sophisticated and novel techniques are considered in this section, along with the more common methods for measuring and evaluating pain.

Some of the tests for distinguishing suffering from malingering are very informal:

The facial expression of true pain-the pinched features, the pallor, the clammy skin, the dilated pupils, the knotted brow-cannot be imitated by the malingerer: these, with the intermittent involuntary cry or groan and the characteristic writhing or bodily contortions, present an unmistakable picture of suffering. ${ }^{87}$

Other tests are more standardized. For example, Mannkopf's sign for suddenly inflicted pain regards an increase in pulse rate of twenty-four to forty-four beats per second as significant. ${ }^{88}$ Although Mannkopf's sign may not be helpful in proving continuous pain, it can be used to

${ }^{84}$ BoNics, op. cit. supra note 83 (ten per cent have pain and dysesthesia); Erasmus, supra note 83 (seldom painful); Henderson \& Smyth, supra note 83 (the great majority are painless); Melzack, The Perception of Pain, 204 Scientific Amzrican 4x, 46 (Feb. 1951) (thirty per cent have pain and five per cent have severe pain).

${ }^{85}$ Walters, Pain and Suffering, Medical Clinics No. AMEr. 485, 492 (March 1952). Compare the statement of Dr. Modlin in note 73 supra, with this excerpt from BonicA, op. cit. supra note 83, 980: "The role of underlying psychoneurosis in the etiology of post-amputation pain is difficult to evaluate as the pain and associated symptomatology produced by an amputation are likely to bring out neurotic tendencies even in stable individuals. I believe that the psychoneurotic manifestation is the result rather than the cause of this disorder." Id. at 980 .

${ }^{86}$ Southern Pac. Co. v. Guthrie, 180 F.2d 295, 303 (9th Cir. 2950) 3 Hickenbottom v. Delaware L. \& W. Ry., 122 N.Y. 91, 95-97, 25 N.E. 279, 279-80 (1890).

"MACBRYDE, op. cit. supra note 46, at 10-11.

8 2 GRAY, ATTORNEY'S TEXTBOOK OF MEDICINE, § 102.11 (1960). 
show that manipulation and movement of an area is painful and use is impaired. ${ }^{89}$ However, in some painful conditions, the pulse rate decreases. It is true with many of the body's systems that the reaction to pain is dependent in large degree upon the type of pain-is it deep pain, i.e., internal, or superficial pain, i.e., near the body surface? Generally, the "fight or flight" reactions are activated by superficial pain and "withdrawal" reactions are activated by deep pain."

Prolonged intense pain may affect the heart and thus alter the T-wave of an electrocardiogram. ${ }^{91}$ The blood pressure may rise with severe pain, ${ }^{92}$ although deep pain may cause it to drop. ${ }^{83}$ Generally, the respiration rate, metabolic rate and temperature increase with pain. ${ }^{94}$ On the other hand, skin resistance to electricity in a superficial pain area is decreased. ${ }^{95}$ A dermometer can be used to determine skin resistance, and areas with low resistance can then be charted..$^{98}$

Palpation, pin pricks and scratch tests are sometimes used in the areas the patient says hurt him. By observing the patient's responses to these irritations-wincing, groaning, voluntary complaint, reflex muscle spasm-the physician can localize the pain and add to his understanding of its nature. ${ }^{97}$ Muscle spasm, because of its involuntary nature, is considered a good indication of pain. ${ }^{98}$

Pain which impairs movement or is activated by movement can be evaluated by observing attempts at movement and reaction to passive movement. Recording devices can be used to measure joint mobility. ${ }^{99}$ When flexion of certain parts of the body produces pain, the involvement of certain nerves is indicated. For example, Lasègue's sign for sciatic pain is observed by raising the leg and increasing tension on the sciatic nerve. If the sciatic nerve is injured or diseased, flexion of the thigh is limited and is painful. ${ }^{100}$ As malingerers may be familiar with

\footnotetext{
${ }^{80}$ See Schmidt v. Chicago City Ry., 239 Ill. 494, 500, 88 N.E. 275, 278 (1909).

${ }^{\circ 0}$ See note 82 supra.

${ }^{91}$ BoNICA, op. cit. supra note 83 , at 159-60.

${ }^{\circ 2}$ Ibid.

${ }^{88}$ Id. at 161 .

"Id. at 160-61.

${ }^{88}$ Id. at $694-97$.

${ }^{8}$ Richter, Instructions for Using the Cutaneous Resistance Recorder, or "Dermometer"..., 3 J. NeUROSURG. 181 (1946).

"Bonica, op. cit. supra note 83 , at 682-83.

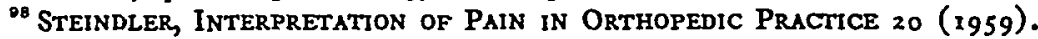

${ }^{\circ}$ Steindler, Kinesiology of the Human BOdX UNDER Normal aNd PathoLOGICAL CONDITIONS II 7-18 (1955).

${ }^{200}$ BonICA, op. cit. supra note 83 , at 751 . The book contains charts listing the
} 
Lasègue's sign, a variation of it in which the patient takes a seated rather than a supine position has been developed. ${ }^{101}$

In cases involving either malingering or psychosomatic pain, these nerve involvement tests may produce unusual results in terms of entirely anatomical and physiological factors. The localization or radiation of the pain may not conform to anatomic patterns. ${ }^{102}$ The pain patterns may be psychologic rather than anatomic in the pain neurotic; i.e., the entire area involved in the subject's traumatic episode may be painful without regard to patterns of innervation. ${ }^{103}$ The non-professional malingerer may be ignorant of the mechanical details of pain experience. Consequently, movement tests, manipulations, or pin-prick tests, for example, may often disclose these unusual pain patterns. ${ }^{104}$ Furthermore, observation of the patient's gait can be valuable to the experienced eye, since different types of pain invite different distributions of weight

various signs, symptoms and tests for various painful conditions. See, for example, the chart on backache and back pain, at 743-49. Traumatic back pain is considered at 74546.

${ }^{101}$ The Beyerle-May sciatic tension test is discussed in Pruce, Clarke \& Clime, Exaggeration of Sympeoms, Malingering and Conversion Reaction, 53 So. M.J. 885, 887 (1960). The authors also suggest other tests to aid the examining physician in trapping malingerers: Dropped pants test-stiff back is found on examination, but agility in pulling pants up, at 887 ; Two-table test-discreetly observe the patient as he goes on and off the examination table, and then on and off the X-ray table. The patient who is simulating stiffness of the back will often relax after completion of his physical examination and functional ranges of motion are demonstrable as he gets on and off the X-ray table, at 886-87. Along the same lines: "It is during the physical examination of the malingerer that he can be fooled into making his fatal mistake. To expose the fraud, it is necessary to confuse the patient. This may be accomplished by visual confusion with mirrors, in reversed images and changed distances. If he can be distracted and confused by doing more than one thing at a time, he will be led into making a mistake. He can frequently be exposed by use of mental confusion, by asking and touching while the patient cannot see." Cantor, Psychosomatic Injury, Traumatic Psychoneurosis, and Law, 6 Clev.-MAR. L. Rev. 428, 436 (1957).

One of the co-authors of the article, Dr. Pruce, advised physicians at a meeting of the American Board of Legal Medicine to avoid labelling patients "malingerer," since this term implies a deliberate intent to deceive which is "difficult to confirm medically and almost impossible to prove legally." He urged a formulation of opinion like this: "After thoughtful and thorough examination the findings make it obvious that the motor and sensory manifestations do not have any organic or structural basis and can be explained only on the basis of conversion hysteria or malingering." 2 Phrsician's LEGAI. BRIEF 4 (Schering Co. No. 7, I960).

${ }^{103}$ MACBRYDE, SIGNS AND SYMPTOMS I53 (1952).

${ }^{103}$ BonicA, op. cit. supra note 83, at 675; Walters, Pain and Suffering, MED. Clinics No. Amer. 485, 495 (March 1952).

${ }^{206}$ Pruce, supra note 101, at 890 . 
and body movements which are difficult for the malingerer to consistently imitate. ${ }^{108}$

It has been pointed out that where the psyche plays a predominant part in a pain experience, the pain may often be relieved by the power of suggestion implicit in the administration of a placebo. ${ }^{108}$ However, very frequently psychogenic pain is not influenced by factors that ordinarily intensify or relieve pain where the cause is primarily physical. ${ }^{107}$ These two phenomena are the basis for the saline-procaine test for determining whether the cause of particular pain is primarily physical or primarily psychic. If the saline does not relieve it, but the procaine, a local anesthetic, does, it is primarily physical. When neither is effective, a severe conversion syndrome or malingering is suspected. "It should be stressed that though this test is clinically valuable, it does not constitute a precise, specific reaction and at best can only serve as an aid to clinical judgment in the evaluation of pain." 108 On the same theory, if a small dose of an analgesic such as aspirin relieves "very severe" pain, psychic factors are probably a large part of the problem. ${ }^{109}$ A record of the pain-relievers administered to a patient can be useful to show, at least, that he complained of pain.110

Because the white blood cell count usually increases when infection is present in the body, an increase is an indication that the patient is probably undergoing pain produced by the infection. Another phenomenon less closely related to pain occurs in the white blood cells during stress situations, since stress reportedly produces changes in the physical make-up of the cells. ${ }^{111}$ Proof that the plaintiff has been subject to stress is of some relevance to his pain experience, as stress can be described as a medical concept of mental pain and suffering. ${ }^{12}$ It would appear that the physical manifestation of stress in the white blood cells is analogous to the "fight or flight" reactions of the sympathetic

\footnotetext{
${ }^{108}$ STEINDLER, op. cit. supra note 98, at 20-21; STEINDLER, op. cit. supra note 99, at $667-83$.

${ }^{100}$ See discussion at notes 55-58 supra.

${ }^{207}$ MACBRyde, op. cit. supra note 102, at 153 .

${ }^{108}$ BonicA, op. cit. supra note 83 , at 684 .

${ }^{100}$ Id. at 685 .

${ }^{110}$ See discussion of pain relievers at note 155 infra.

${ }^{112}$ Wasmuth, Medical Evaluation of Mental Pain and Suffering, 6 CLEv.-Mar. I. REv. 7, 13-15 (1957).

${ }^{12}$ SELYE, The STREss of Life (1956). When the body is subject to stress the tissues are affected (alarm reaction); the affected tissues transmit "messages" which induce a stage of resistance. When a person is already under stress and his resistance is low, additional stress may cause exhaustion.
} 
division of the autonomic nervous system. Perhaps with an increase in emphasis on mental suffering in personal injury litigation, stress tests will become of great interest to the personal injury bar.

On the basis of work such as that with blood cells, it has been optimistically predicted that:

[T] he sciences ultimately will satisfy the requirements of the law with an objective, easily performed and readily available method, to evaluate the human emotions accurately. Such a yardstick will enable the court to assess accurately the damages by mental and emotional disturbance and put it in a position to render to the injured person the full measure of justice to which he is entitled. ${ }^{113}$

Hardy, Wolff and Goodell's device for experimentally inducing pain, the dolorimeter, apparently has met with varied success, depending upon who the commentator is. With the dolorimeter, ${ }^{114}$ light and heat is focused on small areas of blackened skin of the subject at increasing intensities until the subject first perceives pain, at which point his "pain threshold" is reached. The intensity of the light and heat radiation used to reach this threshold is then measured. "Ceiling pain" is determined in the same manner. Degrees of pain are measured in terms of "dols." Zero dols represents the "pain threshold," reached when twenty-two mc./ sec./ $\mathrm{cm}^{2}$ of thermal radiation is used. Ten and one-half dols represents "ceiling pain," which requires $680 \mathrm{mc}$./ sec./ $\mathrm{cm}^{2}$. The experimenters report consistent results with little deviation in "pain threshold" found between persons or in the same person at different times. ${ }^{115}$

113 Wasmuth, supra note 111 , at 16. See also, Wasmuth, Psychosomatic Disease and the Law, 7 Clev.-MAR. L. REv. 34 (1958).

114 Hardy, Wolff \& Goodell, Pain Sensations and Reactions (1952). The dolorimeter is described at pages $67-80$ and instructions for its use are given at pages 80-85. These persons have worked with the "pricking" pain threshold as opposed to other thresholds ("burning," "aching," "reaction") used by other investigators.

New devices are also being used for the alleviation of pain. See, for example, Gardner, Suppression of Pain by Soutzd, 132 ScIENCE 32 (July 1960) (reported effective in ninety per cent of 5,00o cases); Hardy, Wolff \& Goodell, Electrical Anesthesia for Major Surgery, 175 J.A.M.A. 599 (Feb. 18, 1961) (it is reported a number of human subjects have undergone electronarcosis without evidence of deleterious effects of any kind). Dr.'s James G. White and W. H. Sweet successfully used a radio beam to eliminate pain in terminal cancer cases. Address before the International Congress of Neurological Surgery, 1961 .

For use of "machines" in other phases of medicine, see Ledley \& Lusted, Reasoning Foutzdations of Medical Diagnosis, r 30 Scrence 9 (July 1959); Lusted, Medical Electronics, 252 N. ENG. J. MED. 580 (1955).

${ }^{115}$ HARDY, WOLFF \& GOODELL, op. cit. supta note $\mathrm{r}_{14}$, at 88. 
The dolorimeter has been used mainly to test the pain-relieving effects of drugs and in psychological and sociological experiments. ${ }^{116}$ It has also been used for clinical purposes. The patient is asked to compare his own spontaneous, pathologically caused pain with that induced by the dolorimeter. If the patient answers "about the same," and the technician looks at his instruments and determines that the dolorimeter has been giving the subject eight dols of pain, he concludes the spontaneous pain is also of an intensity of eight dols, etc. Hardy, Wolff and Goodell say that although more accurate results are obtained by measuring pain during its occurrence, good estimates can be made from memory. "Thus ... the intensity of a pain can be estimated within a "dol" even after several weeks, although the subject underestimates the intensity of a remembered pain as time goes on."117 Conceivably, this clinical use of the dolorimeter could be adapted to court room use. ${ }^{118}$ Moreover, some physicians use the principle of comparison without a dolorimeter to determine the intensity of pain. They pinch the skin or biceps muscle of the patient with varying force and instruct the patient to compare his spontaneous pain with the pinch pain. ${ }^{119}$

The dolorimeter has been criticized on several counts. Dr. Beecher points out that Hardy, Wolff and Goodell did their dolorimeter work with themselves as subjects. Therefore, the sample was not adequate and bias was not eliminated. ${ }^{120} \mathrm{He}$ concludes that a survey of the literature on the subject shows that the pain threshold is not constant, ${ }^{121}$ and that inconsistency is in accord with the anatomy of pain:

When one couples the anatomical possibilities for communication and spread of impulses with the undoubted fact that determination of a pain threshold requires judgment-i.e., comparison of the non-painful sensation with the barely painful, and this involves memory-it is not difficult to understand how the reaction component could be involved in perception. Pain per-

${ }^{120}$ Some of the data at notes $63-64$ supra, was obtained through use of the dolorimeter. Devices used in conjunction with it include a combination of a food scraper and blood pressure measurement equipment.

${ }_{127}$ HARDY, WOLFF \& GOODELL, op. cit. supra note 114 , at 168.

${ }^{118}$ It was stated in 3953 that dolorimeter experiments were "not sufficiently advanced to cite them as a scientific basis for proof of pain in court." Evaluating Pain and Suffering in Personal Injury Suits, x CUR. MED. ATTNYs. 2, n.1 (Sept. 1953).

120 BonICA, op. cit. supra note 83 , at 675 .

${ }^{230}$ BeEcher, Measurement of SUbJective Responses; QuANtitative Effects OF DRUGS 226 (1959).

${ }^{121}$ Id. at 103 . 
ception is greatly influenced by placebos, by emotion, by anxiety, to mention three more powerful factors at random. ${ }^{122}$

Furthermore, much more emotion and anxiety are involved in accident situations than in experimental pain situations. Consequently, it seems that the entirely different reaction components in the two situations cast doubt on the relevancy of dolorimeter data to pathological pain situations. ${ }^{123}$ Evidence that dolorimeter pain is different from spontaneous pain is presented by dolorimeter studies of the pain threshold on areas of normal skin on persons with skin disease. A wide spread of pain threshold was found. Beecher concludes that the reaction component was responsible for the wide range. That is, the subjects were very much aware of their skin because of disease, and so they responded emotionally to pain even on normal skin. ${ }^{124}$ Likewise, an accident victim views his pain emotionally.

From the above discussion, it can be concluded that we can measure pain only under certain conditions and only for certain purposes. Much of the experimental and clinical work is not germane to proving the intensity of pathologically caused pain in a particular individual. Before any such tests are admitted as evidence, it should be demonstrated that they are relevant in proving the individual plaintiff's pain and suffering. The results of such tests can be attacked on the grounds of improper standardization, inadequate sample, bias on the part of the experimenters, and irrelevancy.

Many of the tests emphasize the pain element in pain and suffering. It has been repeated throughout that the psyche plays a major role in the appreciation of and response to pain sensation. The psyche largely determines how much suffering is caused by the traumatic incident. The point is that the psychologic factors must not be discounted in attempts to overly objectivize the evaluation of pain and suffering.

For court room purposes, the answer must be that we cannot really accurately measure pain. But we can demonstrate that the individual is experiencing pain and approximately how much he is suffering from it. The methods of proving this are discussed in the next section.

\footnotetext{
iss Id. at 110.

${ }^{128}$ Id. at 10, 162 . Beecher lists twenty-seven factors-race, sex, aging, etc., which should be controlled in pain threshold experiments before they can be considered relevant to pathological pain. See id. at chapter 8.

13' Id. at 102 .
} 
III.

\section{Legal Proof of Pain}

\section{A. Expert Testimony}

The above survey of ideas on pain experiences has developed them as complex phenomena which cannot be explained without reference to psychic factors. Depending upon the injuries involved, it may be advantageous in certain cases for medical experts to explain the relevant theories to the jury, since the jury must be made to understand that protestation of pain where there is apparently little physical cause for pain is not necessarily malingering. ${ }^{125}$ Studies tending to prove the various theories should be admissible on the same basis as the theories if they meet the test of relevancy and are shown to be valid and reliable.

Expert testimony is admissible to prove future pain and suffering, and is essential to recovery for such damages where the facts do not give rise to an inference of future pain and suffering. ${ }^{128}$ However, future pain and suffering is not a question of permanent injury which must be corroborated by medical testimony where it is apparent from the nature of the injury that the plaintiff will continue to suffer pain. ${ }^{127}$ When medical testimony is offered to prove future pain and suffering, it must be phrased as "reasonably certain" in some courts" and as a "reasonable probability" in others. ${ }^{129}$ Difficulty is sometimes encountered in eliciting a statement with this requisite degree of certainty from medical wit-

${ }^{295}$ The importance of developing theories of psychogenic pain in some cases is discussed in Olender, The Amount of Pain and Suffering Endured by a Particular Human, 196I Trial and Tort Trentos (Belli ed.).

${ }^{210}$ See Shawnec-Tecumseh Traction Co. v. Griggs, 50 Okla. 566, 567-69, 15 I Pac. 230, 231 (1915).

${ }_{127}$ American Steel Foundries v. Sech, 69 Ind. App. 538, 122 N.E. 347 (1919); Shawnec-Tecumseh Traction Co. v. Griggs, 50 Okla. 566, 567-69, I 5 I Pac. 230, 23 I (1915). See also Brown v. Campbell, 240 Mo. App. 182, 219 S.W.2d 661 (1949); Schultz v. Pittsburgh, 370 Pa. 271, 279-80, 88 A.2d 74, 79 (1952) (jury can assess damages for a reasonable time). In a workmen's compensation case, it has been held that the testimony of the defendant's medical witnesses who said that plaintiff was not suffering from pain which disabled him, but instead was malingering, did not preclude compensation. Apparently, the claimant did not offer opposing medical testimony on this point. Great Western Sugar Co. v. Hewitt, 127 Neb. 790, 257 N.W. 61, 63 (1934).

${ }^{138}$ See Annot., 81 A.L.R. 423, 439 (x932).

29" Id, at 449. Perhaps the difference is only semantic. "The common sense, experience, and conscience of the jury, if responsive, will guide it to the same end, whether it is told that it must be reasonably certain of pain and suffering or satisfied that in all probability or likelihood future pain and suffering will ensue." Coppinger v. Broderick, . 37 Ariz. 473, 477, 295 Pac. 780, $78 \times$ (1931). 
nesses. Perhaps this is attributable to a tendency, by virtue of medical training, to think in terms of more absolute certainty. ${ }^{130}$ Dr. Steindler states the physician's problem:

The orthopedist on the stand is in the uncomfortable position between the two contending factions. In observing strictest objectivity he can never give complete satisfaction to either of the parties, nor should he be expected to do so. The question of whether pain exists should not be laid before him in an absolute form because he is not competent to make an unequivocal statement. The most that can be expected of him is to state whether on the ground of his objective observations, pain as claimed is, or is not, compatible with the condition. This reduces the answer from a positive statement to the level of possibility. ${ }^{131}$

The mere possibility of pain and suffering, however, is not compensable.

The expert witness may express his opinion as to the genuineness of plaintiff's complaints of pain. However, his opinion is not considered conclusive evidence. ${ }^{132}$ Of course, witnesses who are medical experts often offer testimony that is more a narration of events than expert opinion. Perhaps a psychiatrist would be the best witness where malingering is thought to be involved..$^{133}$

\section{B. Statements and Expressions of Pain}

It is undisputed that the plaintiff may testify as to his pain and suffering. ${ }^{184}$

\footnotetext{
${ }^{180}$ See Karlin, Medical Testimony-Problems in Presentation, 12 W. REs. L. REv. $5,6(1960)$.

${ }^{121}$ STEINDLER, op. cit. supra note 98, at 19.

${ }^{132}$ Kirk v. Kansas City Terminal Ry., 27 S.W.2d 739, 744 (Mo. App. 1930),

Tycer v. Hartsell, 184 Ore. 310, 198 P.2d 263, 265 (x948); Gogo v. Continental Casualty Co., 109 Utah 122, 165 P.2d 882 (1946) (suit for disability on health and accident policy); Olsen v. Weitz, 37 Wash. 2d 70, 221 P.2d 537 (1950). The Pennsylvania Supreme Court in 1934 held inadınissible a physician's statement that the plaintiff suffered "the pain he complains of ... [because] pain being a subjective phenomenon, only the person who experiences it is competent to testify as to its actuality." Littman v. Bell Telephone Co., 315 Pa. 370, 172 Atl. 687, 692 (x934). Six years later, a Pennsylvania Superior Court said the admission of a physician's testimony that plaintiff "suffered pain" was not inconsistent with the earlier case: "Here there was no attempt to indicate the intensity of the sensation nor to corroborate testimony as to the precise nature of the subjective phenomenon experienced, as was done in the case referred to." Lutz v. City of Scranton, 140 Pa. Super. 139, 145-46, 13 A.2d 121, 124 (1940). In Eickmann v. St. Louis Public Service Co., 363 Mo. 651, 664, 253 S.W.2d 122, 130 (1952), it was said that "a properly qualified medical witness could better and more accurately arrive at such a conclusion than a lay jury."

${ }^{12 z}$ See Juliver, Psychiatric Opinions as to Credibility. Of Witnesses: A Suggested Approach, 48 CALIF. L. REv. 648, 679-81 (1960).

${ }^{286}[T]$ he injured person naturally was in the best position to tell whether he
} 
Statements of present pain made by a patient to a physician for purpose of treatment are admissible as an exception to the hearsay rule on the theory that the patient will probably tell the truth since the truth is necessary to proper treatment. ${ }^{135}$ That the statements are made after commencement of the lawsuit does not detract from the competency of the evidence, although it may affect its weight. ${ }^{136}$

Statements made by a patient to a physician not for the purpose of obtaining treatment, but for the purpose of qualifying the physician to testify as an expert, are generally inadmissible as hearsay or self-serving declarations. ${ }^{137}$ An exception to this rule has been recognized where the complaints of pain are made in response to manipulations of the injured areas by the examining physician. Such complaints, as opposed to mere narrations, are regarded as part of the res gestae of the pain. ${ }^{138}$ On the same theory, even lay witnesses may testify to spontaneous exclamations of pain. ${ }^{139}$ When, however, the manifestation of pain is more a statement than a spontaneous exclamation, the testimony of lay witnesses has been both received ${ }^{140}$ and rejected. ${ }^{141}$ Necessity has been declared a reason for admitting such evidence. ${ }^{142}$

The above principles deal with present pain and suffering. The older cases held that statements as to past pain and suffering are inadmissible even when made to a treating physician. ${ }^{143}$ Some recent cases

was suffering pain." Employers' Liab. Assur. Corp. v. Industrial Acc. Comm'n, 42 Cal. App. $2 \mathrm{~d} 669,671,109$ P.2d 716, 718 (1941). And in a workmen's compensation case, American Gen. Ins. Co. v. Florez, 327 S.W.2d 643 (Tex. Civ. App. 1959), it was said: "It is recognized that the testimony of the injured party may outweigh that of medical witnesses who are not confronted with the problem of living with the injured member and who are generally not in as good a position as the injured party to evaluate the severity and extent of his pain. ..." Id. at 648 .

${ }^{185}$ La Fave v. Lemke, 3 Wis. 2d 502, 509, 89 N.W.2d 312, 316 (1958). The admissibility of such statements had already been well-established at the time of Lord Ellenborough. Aveson v. Kinnaird, 6 East. 188, 195, 102 Eng. Rep. 1258, 1261 (K.B. I805).

${ }_{180}$ Barber v. Merriam, 93 Mass. (II Allen) 322, 326 (1865).

${ }^{187}$ Atlantic Coast Line Ry. v. Dixon, 207 F.2d 899, 903-04 (5th Cir. 1953).

${ }^{280}$ Atlantic Coast Line Ry. v. Dixon, 207 F.2d 899, 903-04 (5th Cir. 1953); Steele v. Stahelin, 234 Mich. 307,207 N.W. 822 (1926).

${ }^{130}$ Lassiter v. Poss, 85 Ga. App. $785,790,70$ S.E.2d 4 Ir, 4 I5 (1952); CollinsDietz-Morris Co. v. Richardson, 307 P.zd 159, 162 (Okla. 1957). That the injured person may not remember his pain was given as a reason for admitting this kind of testimony in Kennard v. Burton, 25 Me. 39, 46 (1845).

${ }_{140}$ Hamilton v. Doty, 65 N.M. 270, 273, 335 P.2d 1067, 1070 (1959).

${ }^{111}$ Cross v. Blood, 22 Ill. App. 2d 496, 161 N.E.2d 349 (1959).

148 Hamilton v. Doty, 65 N.M. 270, 273, 335 P.2d 1067, 1070 (1959).

${ }^{142}$ Gibler v. Quincy, O. \& K. C. Ry, 129 Mo. App. 93, 104, 107 S.W. 102 I, 1024 (1908). 
have admitted such testimony. ${ }^{144}$ Rule $63(12)(b)$ of the Uniform Rules of Evidence admits such statements unless the judge finds bad faith. It would seem that they should be admitted on the same basis as are statements of present pain made to a treating physician, for it is to the patient's best interest to tell the truth.

\section{Witnesses to Pain and Suffering}

Persons who observed the plaintiff's suffering may testify as to what they saw. ${ }^{148}$ The cases often involve doctors ${ }^{248}$ and nurses, but it is not necessarily as dolorologists or experts that they testify as to their observations. Instead, what qualifies them to testify to what they have seen is the mere fact that they have seen it. The courts generally do not bother to categorize the physician's testimony into expert opinion testimony and mere observation of fact testimony. ${ }^{147}$ In cases involving a nurse's testimony, it has often been expressed that the nurse is testifying simply as a lay witness. 148

Since the nurse is often with the patient in some of his most painful moments shortly after the accident, her testimony can be helpful in establishing pain and suffering, as can that of ambulance attendants and orderlies. A court which affirmed a 90,000 dollar judgment for the death of a fourteen year old girl who had lived for four days after her accident, three of them in a conscious state, reviewed some of the testimony as follows:

According to the doctors and nurses who attended her, she endured the most

\footnotetext{
${ }^{164 E . g ., ~ P e t e r s o n ~ v . ~ R i c h f i e l d ~ P l a z a, ~ I n c ., ~ 252 ~ M i n n . ~ 215, ~ 89 ~ N . W .2 d ~} 712$ (1958).

148 "[The] blank statement that he was suffering was not enough. . . ." Lee v. Swyden, 319 P.2d 1009, 1014 (Okla. 1957) (death action).

${ }^{110}$ One writer suggests that a physician may consider questions on his patient's pain as a reflection on his management of the case. Therefore, he suggests the pain questioning be prefaced with: "I suppose in this type of injury . . . there is normally a certain amount of pain and discomfort, doctor?" CuRran, LAW AND MEDicine 137-38 (1960).

${ }_{167}$ The objection was made in an old case that a conclusion was called for when a physician was asked if the plaintiff suffered pain. The court ruled: "The objection made was that the question called for a conclusion. If 80 , it was one competent for an expert witness to give; but, while the fact might be more keenly appreciated by the person suffering than by an onlooker, it was nevertheless a fact relative to which the onlooker, and especially where he was a physician, might testify." Indianapolis \& M. Rapid Transit Co. v. Reeder, 37 Ind. App. 262, 264, 76 N.E. 816 (1906). (Emphasis added.)

${ }_{168}^{16 . g ., ~ B i m b e r g ~ v . ~ N o r t h e r n ~ P a c . ~ R y ., ~} 217$ Minn. 187, 198, 14 N.W.2d 410, 416, cert. denied, 323 U.S. 752 (1944). "It does not require an expert to tell whether a .person suffera." Kline v. Santa Barbarz Ry., 150 Cal. 74x, 750, 90 Pac. x25, x29 (1907).
} 
intense and excruciating pain. One of the nurses, who was with her constantly on a twelve hour shift, said it was the worst case of burns she had ever seen, and that she had attended many of them. She said that deceased's body was badly swollen and that her face swelled until her eyes were closed and she was still conscious and begging for something to be done to relieve the pain; the nurse finally said that she was simply unable to describe the intensity of the suffering. ${ }^{140}$

Little imagination is required to evaluate the effectiveness of such testimony. The reality of the suffering endured is brought vividly home by descriptions of details such as changing a bed, bathing or even touching the patient and the pain produced by these necessary activities. ${ }^{180}$

The testimony of other witnesses to the suffering can be helpful. A hospital roommate's detailed description of the patient's moaning, crying, and facial expressions, etc., was quoted at length in an opinion affirming the trial court's judgment for the plaintiff. 151 The spouse of the patient, even though he may have had a beneficial interest in the money recovery, has been permitted to relate the suffering he witnessed. ${ }^{152}$

The relation of the suffering may be permitted to involve tinges of opinion, ${ }^{153}$ since even use of the word "suffering" conveys an opinion. The reason given for allowing this semi-opinion testimony is that the witness cannot exactly reproduce the voice, movements, and expressions of suffering as he observed them. ${ }^{104}$

\section{Pain-Relievers}

"Measurement of pain depends upon how much analgesic is required to relieve the pain."180 This principle has been recognized in many

${ }^{160}$ Sandifer Oil Co. v. Dew, 220 Miss. 609, 624, 71 So. 2d 752, 755 (1954).

${ }^{180}$ Smith v. Wichita Transp. Corp., 179 Kan. 8, 17-18, 293 P.2d 242, 249 (1956). The nurse's testimony here was tinged with expertise in that she explained why traction produces a "nerve-wracking" pain.

${ }^{182}$ Mathis v. Atchison, Topeka \& Sante Fe Ry., 61 N.M. 330, 333-34, 300 P.2d 481, 485-86 ( 1956$)$.

${ }_{182}$ Walter v. England, 133 Cal. App. 676, 689, 24 P.2d 930, 935 (1933). In this case the husband was often awakened at night by his wife's crying because of the pain in her jaw. See also Benson v. Smith, 38 S.W.2d 749, 750 (Kan. City App. 193 I).

${ }_{18 s}$ Chicago \& N.W. Ry. v. Green, 164 F.2d 55, 63 (8th Cir. 1947) (workmen's compensation).

${ }_{184}$ Zogg v. O'Bryan, $3 \times 4$ Kan, 821, 828, 237 S.W.2d 511, 515 (1951). A year later, the Kentucky court, after citing the Zogg case, held inadmissible a lay witness' testimony that the plaintiff's arm pained her. Louisville Ry. v. Allen, 246 S.W.2d 443, 447 (Ky. 1 952 ). (1953).

Beecher, A Method for Quantifying the Intensity of Pain, 118 SCIENCE 322, 323 
cases where the administration of pain relievers was considered șignificant evidence of pain and suffering. ${ }^{156}$ It may, in some cases, be advantageous to demonstrate the truth of this principle by referring to the data produced by studies directed at testing and improving pain relieving agents.

A group from Harvard has developed the following technique. Pain-relieving drugs are tested on post-operative wound patients by using a double-blind technique. That is, neither subject nor observer knows whether the test agent or a placebo is being used at any given administration. The patient is asked shortly after administration of an unknown agent whether his pain is at least fifty per cent gone (the arbitrarily set criterion for "relief"). It is reported that patients have no difficulty making this determination. ${ }^{157}$ It is contended that this method provides a more valid means for measuring and understanding pain than do experimental pain methods, such as the dolorimeter, for the psychic elements are not eliminated from consideration. ${ }^{169}$ Consequently, accuracy of results is cited as one of the prime virtues of this method. ${ }^{160}$ Although the data produced is not relevant to proving pain and suffering in a personal injury case, it is germane to demonstrating that analgesic dosage is indicative of the degree of pain.

Hospital records may be used, in accordance with local practice, as evidence of drugs used. ${ }^{161}$ Because of the pressure of too many duties, the nurse's records may not accurately state the dosages given. Resort should then be had to the order sheet from the hospital pharmacy

\footnotetext{
${ }^{108}$ Hubbard v. Long Island R.R., 152 F. Supp. I, 2 (E.D.N.Y. 1957), Gorcycea v. N.Y., N.H. \& H. R.R., 141 Conn. 701, 704, 109 A.2d 589, 591 (1954); Ambrosius Industries v. Adams, 293 S.W.2d 230, 238 (Ky. 1956); Ferne v. Chadderton, ${ }_{363} \mathrm{~Pa}$. 191, 199, 69 A.2d 104, 108 (1949) (wrongful death and survival action); Green v. Rudsenske, 320 S.W.2d 228 (Tex. Civ. App. 1959). Conversely, a dissenting justice has referred to lack of evidence of "so much as one dose of any type of medicine . ..." as a reason for reducing an award. Texarkana Bus Co. v. Carter, zor S.W.2d 300, 303 (Tex. Civ. App. 1957).

For a case where the accident and resulting injury and pain culminated in drug addiction and alcoholism, see McBrearty v. Pennsylvania R.R., (unreported) S.D.N.Y. No. 48-449, 1952), 9 NACCA L.J. 255 (1952). "Addiction to morphine has frequently followed its prolonged use for the relief of pain." WoLfF \& WoLf, PAIN 17 (1958).

${ }_{157}$ BEECHER, op. cit. suppra note 120 , at $46-47$. Some researchers have had the patient keep his own chart, while others have had observers keep records. Id. at 63-64. ${ }^{158}$ The dolorimeter is discussed at note 114 supra.

${ }^{150}$ BEECHER, op. cit. supra note 120 , at 10.

${ }^{180}$ Id. at 54. In 1953, Dr. Bonica thought the dolorimeter more accurate, but the Harvard method more practical. Bonich, The MANAGEMENT of PAIN 186-87 (1953). ${ }^{101}$ See, e.g., Hubbard v. Long Island R.R., 152 F. Supp. i, 2 (E.D.N.Y. 1957).
} 
which contains a record of the drugs ordered for the patient. It has been observed that more detailed and accurate reports can be expected from private duty nurses who often have more time to spend on details. ${ }^{162}$

Belli reports that he has been able to dramatize the significance of drugs administered by having a pharmacologist testify to the effects of the drugs given and by examining the pharmacist concerning the prescriptions he has filled for the plaintiff during the period of illness. ${ }^{183}$ Proper emphasis of the material facts of pain, such as analgesics administered, focuses the jury's attention on the plaintiff's pain and suffering and forces them to consider it as something more than a courtroom concept.

\section{E. Hospital Records}

No attempt will be made here to launch into the vast area of law on the admissibility of hospital records, ${ }^{164}$ but reference should be made in each case to the applicable local rules. Drug charts have been mentioned in the previous sub-section. It should be noted that sometimes a physician's notation of "doing nicely" may be explained away on the witness stand. For example, it may mean only that the patient's recovery is normal, and not that he is experiencing no pain. ${ }^{105}$ Similarly, it may appear from the nurses' records that the plaintiff did not complain of pain, but it may be that the reason for "no complaints" was heavy sedation. ${ }^{168}$

Generally, where admissible, the hospital record may be used as evidence of observable facts, but not of opinions as to malingering. ${ }^{167}$ Of course, the statement "suffering pain" is semi-opinion, but when accompanied by reports of objective manifestations of pain such as drug dosage and moaning, there should be no objection to its admissibility.

\section{F. Demonstrations and Photographs}

In judging the permissibility of court-room demonstrations of the

\footnotetext{
${ }^{102}$ See Cantor, Reading Hospital Records, 1957 TRIal and TORT Trends 295, 305 (Belli ed.).

${ }_{108} 2$ Belli, Modern Trials \$291, at 1627 (1954).

164 See generally Hospital Records, 6 ProOf OF FACTS 131 (1960).

${ }^{105}$ See Cantor, op. cit. supra note 162 , at 306,307 .

I"l Kramer, Medical Aspects of Negligence Cases, Practicing Law Institute, Trial Practice Series: Negligence Cases 12 (1953).

${ }^{107}$ Laundries, Inc. v. Goldberg, 7 I Ga. App. 130, 137, 30 S.E.2d 349, 354 (1944); Lewis v. Woodland, ro1 Ohio App. 442, 445, 140 N.E.2d 322, 325 (1955); Martinez v. Williams, 312 S.W.2d 742, 749 (Tex. Civ. App. 1958). Contra, Allen v. St. Louis Pub. Serv. Co., 365 Mo. 677, 285 S.W.2d 663 (1956).
} 
pain elicited by manipulation or movement of the injured member, the question to be asked is: does the probative value of the exhibition outweigh its tendency to evoke the passion and sympathy of the jury? ${ }^{208}$ Demonstration of a painful disability is a dangerous practice on plaintiff's part, for the courts are wary of simulation. ${ }^{168}$ On the other hand, it is said that possibility of exaggeration should not go to competency but only to credibility. ${ }^{170}$ Unplanned, spontaneous demonstrations of the plaintiff's condition, such as a collapse in the court room, do not require a mistrial. ${ }^{171}$ In a novel opinion, the court cited the plaintiff's tears as a basis for awarding pain and suffering damages:

The jury well could infer that though caused by mental anguish at the memory of his pain and the increased loss of hearing, the physical act of crying is painful and that it was reasonably certain to occur again in the future. ${ }^{172}$

Because of the importance of the visual and auditory senses in cases involving demonstrations, deference is usually given to the discretion of the trial court. ${ }^{173}$

On the theory that one picture is worth a thousand words, pictures of the plaintiff which show the extent of his injuries after the accident and which imply suffering are admissible. ${ }^{174}$ Again, the test is probative value weighed against prejudice, and the discretion of the trial judge is usually upheld. ${ }^{175}$ Photographs of the plaintiff in traction ${ }^{176}$ or wearing a Thomas Collar ${ }^{177}$ have been admitted. In these cases, it is reasoned that the pictures make more understandable the extent of inconvenience and suffering. Color photographs, as well as black and white photographs, are admissible, but the fidelity of either type must be

${ }^{108}$ Lampa v. Hakola, 152 Ore. 626, 630, 55 P.2d 13, 15 (1936): "It would be an exceedingly difficult task for the court to take away the impression upon the jury of the expressions of pain made by the plaintiff. It is impossible to uncook a roasted apple. We think the trial court acted well within its discretion in granting the motion for a new trial."

${ }^{100}$ Peters v. Hockley, 152 Ore. 434, 53 P.2d 1059 (1936).

${ }^{170}$ Arkansas River Packet Co. v. Hobbs, ros Tenn. 29, 58 S.W. 278 (1900).

${ }^{171}$ Ismail v. New York, 18 1 N.Y.S.2d 848 (Sup. Ct. 1959).

${ }^{173}$ Sears, Roebuck \& Co. v. Hartley, 160 F.2d 10x9, 1020 (9th Cir. 1947).

${ }_{173}$ Willoughby v. Zylstra, 5 Cal. App. 2d 297, 301, 42 P.2d 685, 687 (1935).

${ }_{176}$ Packard v. Moore, 9 Cal. 2d 571, 581, 71 P.2d 922, 927 (1937).

${ }^{178}$ West v. Morgan, 345 Pa. 61, 63, 27 A.2d 46, 47 (1942).

176 Herndobler v. Goodwin, 310 Ill. App. 267, 273, 34 N.E.2d 8, 11 (1941); West

v. Morgan, 345 Pa. 61, 63, 27 A.2d 46, 47 (1942).

${ }^{177}$ Lynch v. Baldwin, 187 S.W.2d 273 (Mo. 1938). 
established before they are admitted. ${ }^{178}$ Because of the tendency of some judges to consider color photographs inflammatory, it is good practice to have black and white prints available also.

Although no reported cases have been found concerning the introduction of motion pictures by the plaintiff to prove pain and suffering, there was a workmen's compensation case in which the defendant introduced motion pictures to show that the claimant was not disabled, but the project back-fired. Instead, the court felt that the movies simply demonstrated that the claimant did not have free use of his body. ${ }^{179}$ Perhaps motion pictures would be preferable to live court room demonstrations of disability and pain, since the producers could control their productions to exclude prejudicial matter which could be grounds for mistrial. However, this would have to be done with care to guard against the charge of "rigging."

\section{G. Special Problems in Survival Actions}

Except for testimony from the one suffering pain, the same means of proving pain and suffering are available in survival actions as in ordinary personal injury actions. However, where the deceased died shortly after the incident, special problems are presented. In order to justify compensation for pain and suffering, it must be shown that the deceased lived long enough to experience pain. ${ }^{180}$ It may be that no one observed the decedent in his dying moments. In such cases, circumstantial evidence of conscious suffering has been sufficient. In an early Massachusetts case, a general practitioner's opinion that the victim of asphyxiation had undergone conscious suffering was held sufficient. ${ }^{181}$ His only experience with the particular kind of asphyxiation was via reading. Recovery was allowed for conscious pain and suffering in a recent Arkansas case where the deceased was buried in a cave-in. ${ }^{182}$ The circumstantial evidence upon which the award was based was the county coroner's testimony that a man covered with dirt would live some three

\footnotetext{
${ }^{178}$ See Roring v. Hoggard, 326 P.2d 812, 815 (Okla. 1958); Scott, Medico-legal Photography, 18 RockY MT. L. REv. 173 (2946).

${ }^{170}$ Delery v. Scoggins, 13 So.2d 391,392 (La. App. 1943).

${ }^{180}$ However, $\$ 1,000$ was allowed for deceased's pain and suffering and mental anguish where he "was heard to cry out and to groan after the impact ..." and he died almost instantaneously. Beaty v. Buckeye Fabric Finishing Co., 179 F. Supp. 688 (E.D. Ark. 1959). "Although the court recognizes that excruciating pain and anguish can be experienced in a very short space of time, it is clear in this case that a large award for the benefit of the estate would not be justified." Id, at 695 .

${ }^{281}$ Finnegan v. Fall River Gas Works Co., 159 Mass. 311,34 N.E. 523 (1893).

${ }^{182}$ Erhart v. Hummonds, 334 S.W.2d 869 (Ark. 2960).
} 
or four minutes before being suffocated to death. ${ }^{183}$ That the time element is small does not preclude recovery:

A person in great pain and suffering can live a veritable lifetime in but a brief interval. A 20-minute period of great pain and suffering is not to be shrugged off as infinitesimal, too minute for the law to count or to care. ${ }^{184}$

The courts have split as to whether death by drowning is instantaneous. In a recent case ro,000 dollars was awarded for the pain and suffering of the deceased, who had drowned in a derailed train car. "The decedent was presumably thrown around in the car prior to the precipitation of the car into the river. ...1185 On the other hand, an Oklahoma decision denied recovery for pain and suffering during a drowning in a swimming pool where the deceased's body had been lacerated by a pipe and " $[T]$ hree physicians ... stated in substance that the deceased suffered a great deal of pain and shock for at least three to five minutes immediately prior to death."188

IV.

\section{An Evaluation of Pain and Suffering As An Element of Damages}

One conclusion should be made from this examination of the proof and evaluation of legal pain and suffering. It is apparent that pain and suffering are not amenable to precise measurement but there are many ways to demonstrate approximately the interference with the tortfeasor's victim's ability or potential to live a fairly normal life free from pain and distress. It is submitted that this interference and the methods for proving it, although imperfect, are nevertheless a sufficient basis for awarding compensation.

The arguments against allowing compensation for pain and suffering

${ }^{183}$ Letter from J. L. Kidd, Little Rock, Arkansas, April 5, 196x.

${ }^{184}$ Miller v. Southern Pac. Co., 117 Cal. App. 2d 492, 509, 256 P.2d 603, 613 (x 953 ) (FELA case in which a total award of $\$ 80,000$ was given).

${ }_{185}$ Meehan v. Central R.R., 18 I F. Supp. 594, 625 (S.D.N.Y. 1960). The court distinguished the Meehan facts from those in Beach v. City of St. Joseph, 192 Mich. 296, 158 N.W. I045 (1916), where deceased had been a passenger in an automobile which fell into a stream. Recovery for pain and suffering had been denied although "several witnesses heard cries after the accident, which indicated that the deceased struggled in the water for a short time ... not more than three or four minutes." Id. at 1046. The distinction made by the Meetran court was that Beach did not involve "the preliminaries prior to the precipitation into the stream present in ... [Meehan]." Meehan v. Central R.R., 18 I F. Supp. 594, 626 (S.D. N.Y. 1960).

${ }^{188}$ Fike v. Peters, 175 Okla., 334, 337, 52 P.2d 700, 703 (1935). 
are forcefully presented by Professor Jaffee. ${ }^{187}$ It is realized that discussion without detailed examination of the reasoning may do injustice to his thesis, but it does not seem unfair to outline his thesis as it relates to this discussion as follows:

(I) There is an "arbitrary indeterminateness of the evaluation [of pain and suffering]."1188

(2) Pain and suffering is "an experience which involves no economic loss ...."188

(3) Therefore, "[I] nsurance aside, it is doubtful justice seriously to embarrass a defendant, though negligent, by real economic loss in order to do honor to plaintiff's experience of pain. And insurance present, it is doubtful that the pooled social fund of savings should be charged with sums of indeterminate amount when compensation performs no specific economic function."

The premises should be conceded. But the defendant or the pooled social fund of savings should compensate the victim for the changes effected in his life. Prior to his accident, he had "X" capacity to live a normal life free from the type of pain and distress he has experienced and is expected to experience in the future. After the accident, his ability to do this is only "X-Y." The victim has lost "Y" capacity to live as he might have absent his post-traumatic syndrome. The only question is this: should loss of "Y" be compensable?

The term "compensation" is used throughout the cases. The money awarded cannot really compensate or be equivalent to lost of "Y." Pain and suffering is not like "loss of bargain;" on the contrary, it is unique, but specific performance cannot be had for loss of "Y." Few would argue that it is less valuable than possessions that can be bought and sold. Rather, most would consider it more valuable even though its value is not easily calculated in dollars. However, so long as money is considered a "good" by our society, money should be given the victim in an attempt to counteract his loss of something good. ${ }^{101}$ Otherwise, what

107 Jaffe, Damages for Personal Injury: The Impact of Insurance, 18 LAw \& CoNTEMP. ProB. 219 (1953). His arguments are presented in more recent writings. See Green, Traffic Victims: Tort Law and Insurance (1958) (proposes compulsory loss insurance to supplant negligence law in motor vehicle accident cases with the elimination of pain and suffering as an element of damages); Morris, Liability for Pain and Suffering, 59 CoLUM. L. Rev. 476 (1959).

${ }^{12 s} \mathrm{Jaffe}$, supra note 187 , at 224 .

20: Id. at 224 .

${ }^{100} \mathrm{Id}$, at $224-25$.

${ }^{102}$ When compensation is given for pain and suffering in survival actions, it is diffcult to apply the concept of lessened capacity. "The image of the law affording special pocket money to sufferers for books, television sets, and other distractions from pain is appealing-especially since it looks (abstractly) like no great burden. But the law of 
is the accident victim's quid pro quo? The pain sometimes associated with the dentist's chair is compensated for by the arresting of an unhealthy condition. The pain often accompanying childbirth is compensated for by the life-proclaiming cry of the new son or daughter. What compensation is there for the agony suffered by the tortfeasor's innocent victim? The award of money is, at best, only an attempt at compensation, but it is better than nothing. How much money is given, of course, must depend upon the current attitude of society as represented by the jury or other fact-finder. ${ }^{192}$

\section{A Recommendation}

The jury may be better guided in its deliberations by using more comprehensive labels than "pain and suffering," "embarrassment," and "distress" to represent non-pecuniary losses. Rather, physical and psychic forces combine to present a total picture, and attempts to break down non-pecuniary damages into these various elements are unrealistic. Even where pain and suffering is the only element of non-pecuniary damages, it does not connote everything that plaintiff should be compensated for. What the jury is really asked to find when considering non-pecuniary damages is: How much money should be given this plaintiff to compensate him for the experiences he has had to go through and the changes that have been made in his life as a result of this defendant's negligence? This idea can best be conveyed by use of a label which describes the total non-pecuniary effect of the accident on the plaintiff's life from the moment of impact until his expected death. It is submitted that the jury would be better advised as to what should be involved in assessing non-pecuniary damages if a phrase such as "impairment of ability to live a normal life free from pain and distress" were used.

\footnotetext{
damages for pain is not always calculated to provide only small diversions for sufferers. Courts depart most clearly from that objective where statutes entitle a relative of a mortally injured person to recover for the dead man's pain and suffering." Morris, supra note 187 , at 479 . The quoted observation is most significant where no appreciable time elapses between injury and death. Where death is not quite instantaneous, it seems that allowing recovery for pain and suffering is really a disguised means of punishing the defendant or giving money to the survivors to help compensate them for their loss.

${ }^{102} \mathrm{~A}$ proposal to limit pain and suffering damages to a percentage of special damages suggested in Plant, Damages for Pain and Suffering, I9 OHio ST. L.J. 200, 21 0-1 1 (1958), does not give sufficient weight to the important psychic factors of pain and suffering. These may not be reflected in hospital bills, etc. The same criticism is applicable to a schedule for pain and suffering comparable to those used in workmen's compensation, as was proposed in Zelermyer, Damages for Pain and Suffering, 6 SrrsCUSE L. REv. 27, 41-42 (1.954):
} 